\title{
MORPHOLOGY AND PALAEOENVIRONMENT OF BROOD CELLS OF QUATERNARY GROUND- NESTING SOLITARY BEES (HYMENOPTERA, APIDAE) FROM FUERTEVENTURA, CANARY ISLANDS, SPAIN
}

\author{
Edwards, N. ${ }^{\mathrm{ab}}$, Meco, J.
}

\begin{abstract}
a School of Earth, Environmental and Physical Sciences, University of Portsmouth, Portsmouth PO1 3QL, United Kingdom b Departamento de Biologia, Universidad de Las Palmas de Gran Canaria, Campus Universitario de Tafira, E-35017 Las Palmas, Islas Canarias, Spain
\end{abstract}

\section{Abstract}

On Fuerteventura, the abundance of in situ brood cells of ground-nesting solitary bees in Pleistocene and early Holocene loessic palaeosols and calcretes, and the presence of several taxa of land snails, living species of which occur today in the Mediterranean region and northwest Africa, indicates a semiarid climate, probably with hot, dry summers. Large-scale nesting by solitary bees may have occurred early during European temperate stages. 